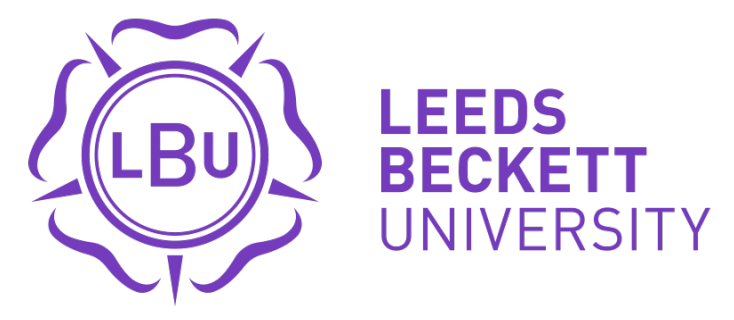

Citation:

Boukas, $\mathrm{N}$ and Ziakas, V and Boustras, G (2013) Olympic legacy and cultural tourism: Exploring the facets of Athens' Olympic heritage. International Journal of Heritage Studies, 19 (2). 203 - 228. ISSN 1352-7258 DOI: https://doi.org/10.1080/13527258.2011.651735

Link to Leeds Beckett Repository record:

https://eprints.leedsbeckett.ac.uk/id/eprint/207/

Document Version:

Article (Accepted Version)

The aim of the Leeds Beckett Repository is to provide open access to our research, as required by funder policies and permitted by publishers and copyright law.

The Leeds Beckett repository holds a wide range of publications, each of which has been checked for copyright and the relevant embargo period has been applied by the Research Services team.

We operate on a standard take-down policy. If you are the author or publisher of an output and you would like it removed from the repository, please contact us and we will investigate on a case-by-case basis.

Each thesis in the repository has been cleared where necessary by the author for third party copyright. If you would like a thesis to be removed from the repository or believe there is an issue with copyright, please contact us on openaccess@leedsbeckett.ac.uk and we will investigate on a case-by-case basis. 


\title{
OLYMPIC LEGACY AND CULTURAL TOURISM: EXPLORING THE FACETS OF ATHENS’ OLYMPIC HERITAGE
}

\author{
Authors \\ Dr Nikolaos Boukas \\ Dr Vassilios Ziakas \\ Dr Georgios Boustras \\ Center for Sustainable Management of Tourism, Sport \& Events \\ European University Cyprus
}

\begin{abstract}
This study examines the effects of the Olympic Games on Athens' cultural tourism and the city's potential to leverage the Olympic legacy in synergy with its rich heritage in order to enhance its tourism product during the post-Games period. In doing so, a qualitative and interpretive approach was employed. This includes a literature review on Athens' 2004 Olympics to identify the sport facilities and regeneration projects, which constitute the Olympic legacy and heritage. Based on that, an empirical analysis was undertaken, by collecting official documents about the 2004 Olympics, and conducting five semi-structured interviews with tourism/administrative officials. The findings indicate that the Olympiad contributed significantly to Athens' built and human heritage, revealing the dimensions of new venues/facilities, infrastructure, transportation and aesthetic image of the city, and human capital enhancement. Hence, the Games contributed to the multifaceted representation and reconstruction of the city's identity and cultural heritage. However, the potential afforded from the post-Olympic Athens remains unrealised due to lack of strategic planning/management. The study concludes that there is a need to develop cross-leveraging synergies between the Olympic legacy and cultural tourism for the host city. Finally, a strategic planning framework for leveraging postGames Olympic tourism is suggested in order to maximise the benefits of Athens' legacy and heritage in the city's tourism development.
\end{abstract}

Keywords: legacy, heritage, cultural tourism, post-event leverage, post-Games Olympic tourism

\section{Introduction}

Legacies of mega-events are multifaceted involving long-term economic, tourism, social, and/or environmental outcomes for the host city/region (Preuss, 2007). In this regard, the legacies of the Olympic Games extend well beyond sport having the capacity to 
accelerate or initiate changes in material/social infrastructure and culture, hence transforming urban order (Essex and Chalkley, 1998; Hiller, 2006). In the pace of change that a host Olympic city undergoes, local identities and cultural heritage are re-shaped. The Olympics as a mega-event invite a host city's, and even a nation's, people to take on new identities as citizens of the world (Horne, 2007). Also, by their very nature as a ramified cultural performance, the Olympics comprise different genres, which are interconnected at many levels (i.e., historically, socially, functionally, performatively) and they act and react upon another constructing shared meaning and new versions of reality (MacAloon, 1984). Thus, the resulting changes in a host city's sense of place can be traced to the facets that its heritage and reinvented identity take in its interplay with the Olympics.

From a tourism standpoint, as host destinations strive to harness their Olympic legacies and create a unique place identity (Weed, 2008), they apparently reconfigure their cultural heritage in order to improve their qualities and image. In this process of developing an Olympic city as a cultural product, Beriatos and Gospodini (2004) demonstrated in the case of Athens' 2004 Olympic Games that urban historic preservation (where place identity is rooted) converged with innovative designs (that display all the signs of a contemporary city) yielding a 'glocalised' urban landscape. Khirfan (2010) added in this process the symbolic significance of the city's intangible heritage in cultivating its distinctive spirit of place through the reuse of urban palimpsest, which carries both tangible traces (e.g., streets, plazas, and buildings) and symbolic traces. The latter evoke collective memory and trigger new rituals, events and activities that bind residents, establish continuity from the past and synchronise it with the present.

Indeed, one of the main aims of Athens' Olympics was to link historic heritage (as birthplace of the Games) with modern capabilities and hence rejuvenate its tourism industry (and Greece's by large). The world-wide exposure the city gained provided an opportunity to reposition itself from a destination with mass characteristics to a highquality/diversified one. Despite the economic, social and environmental burdens the Olympic Games brought (Dagli, 1998; Potsiou and Zentelis, 2005), in terms of tourism development they contributed towards re-imaging the city and upgrading its infrastructure (Asprogerakas, 2007; Beriatos and Gospodini, 2004; Koutoulas et al., 
2009). However, the lack of strategic planning for the post-Olympic use of the newly constructed facilities (Beriatos, 2006; Zifou et al., 2004) has also led to an inability to develop a competitive post-Olympic tourism product (Weed, 2008). In this context, the successful hosting of the 2004 Olympics' legacy remains a prosperous asset that Athens may capitalise upon in order to revive its tourism industry.

Considering that cultural tourism represents Athens' major form of tourism (Kalogeropoulou, 1996; Papageorgiou-Venetas, 1996), it is critical for the city to link its Olympic legacy to its cultural tourism product. Athens is for many people the cradle of democracy. According to Richards (1996), a significant percentage of the Greek cultural attractions are concentrated in Athens. Moreover, according to the Irish Tourist Board (1988), the city has 16 cultural attractions listed in the European Community Inventory of Cultural Tourism Resources. The rich heritage of the city imbued with symbols and meanings attached to its monuments, especially Acropolis, present Athens as the 'birthplace of modern civilization’ (Travlou, 2002, p. 116). Furthermore, the rejuvenation of the modern Olympic Games that took place in Athens in 1896 reinforced the already rich cultural product of Athens and connected the city to the spirit of the Olympics. With the organisation of the Olympics in 2004, this spirit was enhanced further and gave more opportunities to enrich Athens' existent cultural tourism product. Therefore, the above reasons amplify the importance of the development and projection of Athenian cultural tourism and its connection to its valuable Olympic legacy.

The purpose of this study is to examine the effects of the Olympics on Athens' cultural heritage tourism and the potential for leverage in the post-Games period. In this respect, the study investigates Athens' potential to capitalise on the Olympic legacy in synergy with its rich heritage and cultural assets in order to enhance its tourism product. Based on the findings of the study, this paper discusses: (1) the built and human heritage of the Olympic Games, (2) the impacts of the Olympics on Athens' cultural heritage, and (3) the use of Olympic legacy as a means to further develop Athens' cultural tourism. Finally, a framework for leveraging post-Games Olympic tourism is proposed. 


\section{Towards leveraging Olympic legacy and heritage: maximising benefits for sport and cultural heritage tourism in the post-games period}

Legacy of sport events has been defined as the planned and unplanned, positive and negative, intangible and tangible structures created through a sport event that remain after the event (Gratton and Preuss, 2008). Hosting the Olympic Games drives a city to invest public funds for building new facilities and infrastructure and planning urban regeneration projects, which can leave favourable or unfavourable legacies for residents (Essex and Chalkley, 1998; Gold and Gold, 2011; Horne, 2007; Mangan and Dyreson, 2009). While there has been sufficient research on the political, economic and tourismrelated impacts of the Olympics (e.g., Brown et al., 2004; Burbank et al., 2001; Roche, 2000; Weed, 2008), there has been less attention on how the construction of the Olympic facilities is related to the long-term goals of the city in terms of the post-event consequences to the built environment and urban processes (Hiller, 2006). This refers not only to the post-event usage of the structures created for the Olympics itself, but also to the side effects or parallel linkages (Hiller, 1998) that transform the urban environment and consequently the identity and sense of place of the Olympic host city.

In this regard, the heritage of the city is reconstructed or reinvented in its interplay with the Olympics. MacAloon (1984) explained that the Olympics as a ramified cultural performance system composed of the genres of spectacle, festival, ritual, and game fosters communitas, which transcends the political, racial, ethnic, and linguistic boundaries that divide humans from one another. In other words, the liminoid nature of the Olympics creates a sense of interconnectedness for people who feel as equals and engage in metaphoric discourse dealing with matters of worldwide importance. The encounter of communitas and the global attention it brings is itself a legacy for the host city, which along with the changes in the built environment transforms the urban order and culture. In addition, the cultural dimension of the Olympics through the Cultural Olympiad can bring about more direct influences on the host city's cultural heritage (Gold and Revill, 2011). 
Consequently, being an Olympic host allows a city to commemorate this fact through its inclusion as a historic marker in the city’s history, which provides global exposure and recognition (Hiller, 2006). This is also connected with the construction of sport heritage that cities exploit through the use of sport and sports venues as heritage tourism attractions (Gammon and Ramshaw, 2007; Ramshaw, 2010; Ramshaw and Gammon, 2010). However, the interest of the public may wane as time passes after the Games and attention is directed towards new Olympic cities. Thus, the issue is how the post-Olympic legacies can be preserved and transformed in the long-term. In this respect, it is critical to consider the socio-cultural and psychological legacies that may enhance the long-term well-being or lifestyle of residents in a very substantial manner by reflecting the values of the local population (Ritchie, 2000). For example, Waitt (2003) evidenced the changes in enthusiasm, in the pre-Games period, between 1998 and 2000 towards Sydney's Olympics among host city residents, showing that for the majority the reaction to Sydney's Olympics intensified from 1998, reaching euphoria in September 2000. Hence, if it is to fully capture the socio-cultural effects of the Olympics, it is heuristically useful to know what happens in the post-Games period in terms of how the Games are incorporated in the collective memory, culture and heritage of the host city. This calls for examining the interactions between a city's heritage and the shaping of Olympic-related urban forms by identifying the links between the distinctive spirit of place, the symbolic significance of heritage, and the resulting post-Olympic urban form. In order to understand these interactions of a host city’s Olympic heritage a useful theoretical framework is the analogy of palimpsest.

In particular, cities are continuously evolving and their forms change as their components and associated characteristics acquire new meanings and functions (Kostof, 1991). In this regard, the urban landscape is thought to resemble the palimpsest, which is the writing block or parchment that can be erased and reused several times, leaving traces and redundancies that remain as a mark of the past or an inheritance (Crang, 1996). This in turn is transformed into heritage superimposing a new urban layer over the previous one (Khirfan, 2010). Whether intangible or tangible, heritage acquires symbolic significance that stems from its architectural, memorial, or contemporary importance and reflects its aesthetic, historic, scientific, social or spiritual value for past, present or future 
generations (Tyler, 2000). The significance of the historic fabric naturally makes the city an attraction for tourists; hence, heritage tourism becomes an urban reality incorporated into the city’s daily activities (Ashworth and Tunbridge, 1990). As such, a reconstruction and reinterpretation of heritage symbolism takes place fostering a collective experience of urban space that transforms the urban form into a cosmic one (Khirfan, 2010). In other words, the reinterpretations of the symbolic significance of tangible and intangible heritage, combined with innovative designs and rituals, generate a collective experience of the new urban layer and transform the emerging urban form into a contemporary cosmic one (Khirfan, 2010).

How the transformation and reinterpretation of an Olympic host city's heritage can be harnessed to attract global attention and tourism? Ritchie (2000) suggested that legacy planning for the Olympics can lead to the attainment of long-term benefits to host destination residents. Legacies can represent a platform for future tourism development if local policies demonstrate the ability to re-territorialise the temporary transforming effects on tourism into long-lasting ones (Dansero and Puttilli, 2010). This requires strategic planning for creating and leveraging the legacies of the Olympics in the longterm in order to achieve and maximise sustainable outcomes (Chalip, 2004; Gratton and Preuss, 2008; O’Brien, 2006; Preuss, 2007). Towards this direction, Weed (2008) has extended Chalip’s (2004) general model for sport event leverage to the Olympic context examining the way in which the Olympic Games can be harnessed as a leverageable resource and identifying the opportunities of Olympic tourism (i.e., strategies directly focused on generating Olympic tourism in the pre-, during, and post-Games periods), and Olympic media (i.e., strategies focused on using Olympic media to enhance destination image and thus lead to a longer-term boost in both sport-related and generic tourism businesses). In particular, the means to leverage Olympic tourism benefits are the following: enticing Olympic tourism spending, retaining local resident spending, lengthening Olympic-related visits and maximising Olympic-related visits. The means to leverage Olympic media in order to enhance the image of the Olympic host destination are the Olympic-related reporting and event coverage as well as the use of Olympics in host destination advertising and promotion (Weed, 2008). 
According to Chalip (2006), event leveraging requires that events be studied with reference to the efficacy with which the host destination's product and service mix was employed to enhance the event's impacts. Similarly, leveraging of the Olympic legacies in the post-Games period is a matter of the host city's overall use of assets and services that impact upon its capacity to maximise the Olympic-related benefits. Therefore, effective leveraging programmes should cross-leverage the Olympics with the overall assets of the host city's heritage/culture, sport/cultural events, and sport/cultural tourism product mix.

\section{Method}

A qualitative and interpretive case study approach was employed (Creswell, 2006; Denzin and Lincoln, 2005) in order to analyse the multifaceted aspects of Olympic heritage and its connection to place identity as well as sport and cultural tourism. A single-case study was used because it can thoroughly describe the existence of the phenomenon under study and thus provide a credible and convincing argument about causal forces (Eisenhardt and Graebner, 2007; Siggelkow, 2007). Given Athens' heritage as the birthplace of the Olympic ideals, the case of Athens represents an appropriate context to interrogate the relation amongst Olympic Games, historic continuity and transformation as well as cultural representation. This interrogation can reveal how the connection of the present with the past exemplified through the Olympic structures and symbolisms reconstructs the cultural heritage and constituency of an Olympic city, hence building a diachronic multifaceted legacy for the Games.

Data was collected from multiple sources of evidence in order to increase the validity/reliability of the findings (Yin, 2009). At first stage, a literature review was undertaken on Athens' 2004 Olympics in order to identify the sport facilities and regeneration projects that constitute the heritage of the Olympics. The findings were compiled into one document, which served as a basis for the subsequent empirical analysis. This revealed the built and human heritage of Athens' 2004 Olympics as emanated from the literature review. The empirical analysis is based on data collected 
through official documents and reports about the 2004 Athens’ Olympic Games as well as semi-structured interviews conducted with tourism policy-makers and administrative authorities.

The document analysis undertaken adopted an interpretive approach to understand the meanings, dimensions and effects of Olympic heritage as evidenced in official reports. The coding of data followed a standard protocol (Miles and Huberman, 1994). Firstly, an initial open coding of all Olympic-heritage themes was carried out by reading through each textual source. This aimed at identifying emerging themes that appeared and reoccurred throughout the different reports. Coding was conducted on excerpts that referenced aspects of Olympic legacy and heritage in terms of both short-term and longterm outcomes for Athens. The excerpts were then further analysed focusing on the following emerging themes: (1) impacts of Athens' 2004 Olympics on cultural heritage, and (2) use of Athens' Olympic legacy and heritage in cultural tourism. These coding themes were checked between co-authors for reliability.

On the basis of the above emerging themes, five in-depth semi-structured interviews were conducted in order to probe into the major factors and issues that shape the Olympic heritage and affect its leveraging potential for sport and cultural tourism in the post-Games period. Specifically, two interviews were conducted with officials from the Ministry of Tourism (now named Ministry of Culture and Tourism), two with officials from the Greek National Tourism Organisation (GNTO), and one with an executive from a company related to the management of Olympic properties. The interviews were conducted in the offices of the interviewees by two co-authors and lasted 30-40 minutes. The questions focused on the themes identified from the document analysis and probes were used to elicit in-depth responses into major issues. The interviews were tape-recorded and then transcribed verbatim and translated into English. The transcripts were reviewed, discussed and analysed by the co-authors as they fitted and explained each theme from the document analysis. To increase the reliability of the results, the authors returned to the literature for triangulation (Eisenhardt, 1989). As such, the analysis interpreted and synthesised the findings in line with the literature. The presentation of findings is structured according to the emerging coding themes of the study and incorporating pertinent literature. 


\section{Built and human heritage of Athens' 2004 Olympics}

The 2004 Olympiad was viewed from the beginning of the bidding process as a unique opportunity for Athens to reshape its profile as a contemporary European city. In fact, the Games endued Athens with several types of infrastructure and enhanced its image. Moreover, the organisation of such a mega-event encompassed investment in the human capital of the city. In this respect, the Olympics contributed variously in Athens' built and human heritage. This contribution can be described as a three-dimensional process: firstly, the built heritage of Athens was enhanced by the construction of new venues and facilities, secondly, the city's infrastructure, transportation and aesthetic image has been highly improved, and thirdly, the residents of Athens had a unique chance to experience and to actively participate in the organisation of the most significant event that the city hosted since the first modern Olympiad of 1896.

In terms of the significance of the Olympics in the city's infrastructure, Tziralis et al. (2006) argue that the sustainable impact on Athens can be justified by the permanent character of the constructed facilities. As they report, from the total 1.975 billion Euros spent for the renovation or construction of Olympic facilities, only 10.2\% concerned temporal facilities.

\section{First dimension: new venues and facilities}

Athens -and Attica's prefecture in general- inherited a significant number of new and/or renovated sport venues and facilities from the Games (Table 1). All these venues were of significant importance for the successful conduct of the event, even though their subsequent utilisation is questionable (Gold, 2011). Also, the construction and/or renovation of venues formed clusters of athletics, culture and leisure that constitute epicentres of economic and socio-cultural activity in the respective sectors (Gospodini, 2009). The main complex of venues that starred during the event was the Olympic Athletic Centre of Athens (OAKA) at the North of the city, where the opening and 
closing ceremonies took place. The Complex was constructed for the European Athletic Championships in 1982 (Gold, 2011). However, due to the Olympics' organisation it was fully renovated. The most distinctive features in the Complex were designed by the Spanish Architect Santiago Calatrava and included a series of interventions such as the construction of the two leaf roof from laminated glass for the main Olympic Stadium, the roof of the Olympic Velodrome, as well as several other interventions to the surrounding areas, such as the Agora, a vaulted modular structure formed as an arc, or the Wall of Nations -a sculpture of tubular steel designed for mechanically moving in a wavelike motion that was used as a giant video screen (OAKA, 2011). The Olympic stadium resurrected the ideals of Hellenism, which were embodied into a contemporary, highly technological construct that became symbolic of Greece's entrance to the 21st century (Traganou, 2008, 2009). Additionally, the landscape of the Complex was enriched by the construction of water ponds, paths and tree planting. Currently, the venues of the Complex are used for sport events and concerts.

\section{[TABLE 1]}

The second complex located at the Southern part of the city was the Faliro Bay Complex. The location includes two adjacent sites: the coastline where two rivers conclude and the site of the former Athens racetrack (Zifou et al. 2004). For many years the area was deteriorating (Kissoudi, 2008). According to Gold (211, p. 323):

'This area had developed in the 1870s as an elegant resort serving the Athenian middle class but a century later, cut off from adjacent residential districts by the coastal highway, it had declined into a virtual no man's land, degraded, polluted, and an illegal dumping ground'.

For the above reasons one of the main aims of the Games' organisation was the unification of the urban landscape with the coastline of the South (Kissoudi, 2008; Sykianaki, 2006; Zografos and Defner, 2007) and the regeneration of the coastal zone, including the creation of a marina for water sports (Cartalis, 2003). The Faliro Bay 
Complex includes the Faliro Pavilion, the Olympic Beach Volley, the senior and fully renovated Karaiskaki and Peace and Friendship stadia, as well as the areas of the coastline (between the outfalls of Kifisos and Ilisos Rivers) and the Southeast edge of Faliro Pole (between the areas of Tae Kwon Do and Marina of Floisvos). The whole area was remodelled and cleared, leaving the space open for the public. Currently, the venues of the Complex are used for commercial and retailing activities, concerts and sporting events. Furthermore, there are plans for transforming part of the area into an ecological park and green spaces (Olympic Properties, 2008). However, until today these plans have not been implemented yet while large parts of the area are isolated.

The third complex of venues was the former International Airport of Athens, Hellinikon. In the large area of Hellinikon several venues were built such as the Hellinikon Olympic Indoor Arena hosting the sports of basketball, handball and fencing, the Hellinikon Hockey Centre and the Hellinikon Canoe/Kayak/Slalom. Many of these venues are currently used for concerts or sport events. The Hellinikon Canoe/Kayak/Slalom has been transformed into a sport centre and a water/theme park (Olympic Properties, 2008). Plans also include the creation of one of the largest European metropolitan parks (Gold, 2011). However, this attempt has not yet been implemented. As Milionis (2010, p. 170) indicates:

'Pressures from various interest groups such as municipal authorities, central government politicians, local pressure groups, academics, established agencies [...] private developers each one of them with a different agenda in mind, have hindered any serious effort for formulating a definite and comprehensive development plan'.

Apart from the above main complexes, other venues that revitalised Athens included the International Broadcast Centre (IBC) at the North of Athens, that has been currently transformed by a private company into a mall while the museums to be operated in the building have not been developed yet (Gold, 2011), the Nikea Arena (located at the South East of Piraeus) that now belongs to the University of Piraeus and serves the needs of academics and students, the Goudi Complex (located at the North East of Athens) that 
has been transformed by a private company into a modern theatre, and/or the Olympic village that now hosts almost 11,000 residents (Olympicvillagenews, 2011).

\section{Second dimension: infrastructure, transportation and aesthetic image}

The Olympics had a significant positive impact on the city’s infrastructure and cultural/aesthetic image. According to Boniface and Cooper (2005), the Olympics were the catalyst for Athens' urban regeneration. Obviously, the construction of the venues and facilities themselves contributed to the regeneration of degraded areas such as the aforementioned Faliro Zone. In addition, a series of infrastructure works such as constructions, painting, modernising, cleaning (that seriously added to the beautification, renovation and modernisation of the city) took place a long time prior the Games, while lasted literally until the last moment (Kissoudi, 2008).

In terms of urban interventions, Beriatos and Gospodini (2004) argue that the projects of Athens were classified in three main categories. The first category included projects related to the built heritage such as the pedestrianisation of the roads linking to archaeological sites, the restoration of cultural places and monuments, the renovation of buildings and properties, and/or the renovation of building facades. The second category included the projects that were related to the innovative transformation of space, such as design schemes with modern elements contracted through national and international competitions (e.g., the Calatrava's design and buildings). The third category included the 'non-competitive' projects related to the upgrading of the urban space (e.g., transportation infrastructures such as roads and junctions or metro lines) and beautification of open spaces through micro-scale redesign schemes such as the removal of advertising billboards, or façade-renovation of contemporary buildings. Additionally, one of the measures for the upgrading of the city was the incentives given by the government to the manufacturing industries for moving out (Boniface and Cooper, 2005). Another aspect is related to the enhancement of tourism and hospitality facilities. Because of the organisation of the Olympics, new hotels were built and many were renovated contributing thus to the increase of the market values of the city up to $35 \%$ (Zentelis and Labropoulos, 2004). Tsartas et al. (2008) mention that although the 
Olympics did not increase significantly the number of lodging units of Athens, they helped to their upgrading in terms of quality. They argue that there was an increase of four and five stars hotels while, at the same time, a decrease of one and two stars hotels was noted. However, this did not have a significant impact on tourist arrivals. As Figure 1 shows, tourism arrivals in Athens were moderately increased in the first three years after the Olympics, while after 2007 there is a steady decline. Despite the fall, the Olympic legacy as part of the city's heritage has been a basic parameter of the country's national marketing policy (Tsartas et al., 2008).

\section{[FIGURE 1]}

One of the most significant contributions of the Games to the city's tangible heritage is related to the improvement of the transportation system. The Olympics changed the metropolitan area of Athens by adding new transportation means such as the Athens' tram, a means characterised as purely Olympic (Zografos and Deffner, 2007) that connected the centre of Athens with its eastern coast (and the Olympic Complexes of Faliro and Hellinikon) along the coastline. Also, a new underground railway system with an operation distance of $160 \mathrm{~km}$ connecting more than 20 municipalities of Attica and a new suburban railway that connected the new Athens International Airport Eleftherios Venizelos with the city's centre and three more cities were also constructed (Tziralis et al., 2006). Furthermore, an expansion of the city's road network includes several avenues and motorways such as Attiki Odos a 65km motorway with 32 main interchanges, or the Kifisos Avenue that connects the national highway to the South of Athens (Potsiou and Zentelis, 2005). Moreover, for the implementation of the Transportation Plan for the Games, environmental protection issues were taken into consideration for the strategic decision process, even though they were not fully implemented (Zagorianakos, 2004). Undoubtedly, the Olympics were the milestone for the construction and improvement of the public transport system and became the motive to fulfil several tasks on time.

In terms of cultural facilities and activities, the cultural sector has been enriched from new performance and exhibition spaces, renovated museums and archaeological sites (Potsiou and Zentelis, 2005). Indeed, major museums of Athens and the surrounding 
areas have been renovated, such as the National Archaeological Museum and the Byzantine Museum. Another inspired construction that was meant to be completed for the Olympics but was not finally completed until June 2009, is the New Acropolis Museum designed by the architect Bernard Tschumi. The museum is located at the foothill of Acropolis and houses the exhibits of Parthenon. Finally, the Olympics benefited the transformation of degraded areas into places of contemporary arts such as Technopolis in Gazi, a former industrial area that was transformed into a place of arts or Athinais, a renovated silk factory that now offers a theatre, cinema, restaurants, and cafes (Gold, 2011).

\section{Third dimension: human capital enhancement}

The Olympics enhanced Athens' human capital mainly through the increased levels of volunteerism during the Games and the creation of a positive attitude towards them. Indeed, the volunteers in Athens constituted one of the most successful aspects during the Games, since they created a positive image, strengthening this way, the image of Greek hospitality. Moreover, the Olympics shaped a positive attitude towards volunteerism. According to the European Commission Citizenship (2005, p. 2): 'in addition to the 30,000-32,000 regular volunteers, there had been another 45,000 persons volunteering during the Athens 2004 Olympics and it is expected that 25,000 persons will volunteer during the Athens Special Olympics in 2011'. Karkatsoulis et al. (2005) argue that the fact that overall 160,000 people applied as volunteers for the original 45,000 positions during the Olympiad signifies the massive impact the Games had on the whole Hellenism. Furthermore, the authors add that the Athens' Olympics had an added value for the Hellenic identity in terms of volunteers' motivation and increased productivity.

Finally, the Games provided a unique opportunity for exchanging know-how and good practices with other host cities/countries (Potsiou and Zentelis, 2004). Moreover, according to Gold (2011), the Olympics were viewed as a way for fulfilling place promotion aims and the 'soft legacy' of support activities, training, employment, shifts in attitudes and the knowledge of planning and organising a successful event. In this respect, 
the human legacy of the Games was enriched adding more value to the post-Olympic Athens.

\section{Impacts of Athens’ 2004 Olympics on cultural heritage}

\section{Heritage, identity and sense of place}

The impact of the Games on Athens' heritage and identity can be signified by observations such as: 'Greece had an opportunity to improve the general quality of life in the host city and promote athletic, economic and cultural development' (Kissoudi, 2010, p. 92). This impact though, is not limited only on the tangible heritage of the Games. As the Former Greek Prime Minister Kostas Karamanlis announced: 'The Olympic Games of Athens, aside the more stadia, facilities and infrastructures, left to our country -as intangible heritage- more maturity, more optimism and more confidence' (Prime Minister's Press Office, 2005, n.p.). In this respect, it was the intention of the Greek policy to enhance the city's heritage and reinforce its identity through the legacy of the Olympics. This could contribute to the representation and further projection of Athens among the hierarchy of contemporary European cities.

The Games stimulated a new socio-cultural change and enriched Athens’ cultural heritage. According to one official, the Olympics promoted a positive image for Athens:

'During the Games the city was 'alive’ with several parties and cultural activities that were taking place in various points of Athens. This created a positive mood and gave 'rhythm in the air'. So there was a celebratory atmosphere surrounding the entire area.

The celebratory atmosphere of Olympic Athens was projected worldwide. For instance, the Washington Post wrote: 'But if Athens will be remembered as one of the most richly atmospheric Olympics, it also had to be credited as modern and wellorganised, which no one would have predicted' (Jenkins, 2004, n.p.). 
According to another respondent, the various cultural events organised during the Olympics in Athens under the auspices of the Cultural Olympiad, provided the opportunity to exploit its cultural wealth, and connected the elements of high culture (e.g., the Parthenon, the National Archaeological Museum) with those of popular culture (e.g., street festivals and events). This amalgam created a unique environment where multiple cultures met in one space and exchanged ideas, lifestyles, and 'philosophies'. As evidenced in the literature, the various events around the urban landscape, not only act as portals for the shaping of the image of the host community to (potential) visitors, but they also contribute highly to the formation of a community's identity, structuring this way an appealing authenticity (Derrett, 2004). Thus, the Olympics managed to project Athens to its visitors while at the same time strengthened the city's identity to its residents.

In this regard, the organisation of the Athens' Olympics gave a particular emphasis on the triangle: Human Scale-Participation-Celebration. According to the Organising Committee, ATHENS 2004 (2004, p. 15):

\footnotetext{
'This vision for the Games was incorporated into all Olympic Games design elements and applications. This comprehensive approach to design resulted in the most impressive image and identity programme in the history of the Olympic Games. The Athens 2004 image and identity was found in the Olympic Games emblem, the Olympic cauldron and torches, the architecture of the venues and Olympic complexes, the design of the Olympic medals and sport pictograms, and the Look of the Games programme’.
}

All the above elements promoted significantly the ideals of the Ancient Olympics and integrated them into the modern ones. It is not on chance that the main catchphrase/motto during that period was: 'The Games return back home'. Moreover, the announcement at the Opening Ceremony was: 'Citizens of the world welcome to Athens' celebration. Olympic Games, welcome back to Greece’ (Feloukatzi, 2004), underlying the huge effort of the small country that gave birth to Olympism, to host the Olympics for the second 
time in modern history. This projection enhanced modern identity and increased the morale and pride of the residents in their city (Karkatsoulis et al., 2005).

However, it is inevitable that after several years from hosting the Olympics, the spirit that was fostered during the Games gradually fades. This occurrence is exacerbated by the fact that many of the Olympic venues remain unutilised, Greeks still need to pay an enormous debt that the Games left behind, while the Greek Government needs to deal with the problem of the economic crisis (and its social dimensions), as well as with the management of several venues and facilities (Gold, 2011). Additionally, as Kissoudi (2010, p. 104) states: 'The spectacle of modern, expensive Olympic assets in a state of despair is at least disappointing and understandably provokes the indignation of the Greek people, who have paid dearly and will long continue paying for these facilities'. Moreover, the negative publicity in the international media highlighted constantly these problems. As a result, a frustration is reflected in various aspects of the daily life including culture. As mentioned by one of the respondents: 'The celebratory atmosphere that existed during the Olympics is not reality anymore and if someone visits Athens today will confront a negative situation and eventually will be dissatisfied'. In this regard, the Olympics transformed the city into a new competitive metropolitan area making all the Greeks proud for their legacy. On the other hand, the management of this legacy after the Games, characterised by slow pace and inadequate organisation (Kissoudi, 2010; Weed, 2008), left the citizens frustrated with the lost opportunities and the negative aspects of post-Olympic Greece. In fact, there is a reasonable argument that the lack of long-term sustainable planning for hosting the Olympics has had a significant impact on the country's current economic crisis by distributing public funds to cover the escalating cost of the Games, without ensuring any return on investment. As such, even though Games' legacy has been significantly altered in line with the economic crisis, it is widely recognised that the Olympic legacy contributed to the revitalisation of the city's heritage identity and sense of place. 


\section{Interchanges between past and present}

The significance of the Olympic Games for Athens lies in the role of the city both as the literal and spiritual home of the Games as well as a recent host. According to Kitroeff (2004), Greece views its role as both the affirmation of the ancient heritage and a means to gain international recognition, epitomising the efficiency, modernity and European values that currently characterise Athens. In this respect, both modern Olympic Games (1896 and 2004) were seen as challenges that were very difficult for the country not to deal with.

One of the main impacts of the Olympics is the transformation of a city with several problems such as unequal spatial development, environmental pollution, problematic transport system, degraded built fabric, extremely grown the recent decades due to the rural immigration (Beriatos and Gospodini, 2004), into a contemporary metropolitan European city with modern profile (Kissoudi, 2010). In fact, the Olympics limited or vanished some of these problems. In terms of culture, one of the main interventions that the Olympics brought to Athens is the conservation of its historic buildings and the enhancement of its cultural network. As Beriatos and Gospodini (2004) suggest, this was managed by unifying and integrating many of the city's monuments and archaeological spaces and connecting them through a network of pedestrian roads, creating this way a cultural itinerary of its centre. The authors add that along with the introduction of innovative contemporary designs in the urban morphology, the urban historic preservation led to the 'glocalisation' of urban landscapes encompassing a unique 'spirituality' that makes Athens distinctive across the globe. Thus, the impact of Athens' Olympics on its cultural heritage is the construction of a 'glocalised' physiognomy that underlines the city uniqueness. The Olympics revitalised the tangible elements of cultural heritage (i.e., unification of the archaeological spaces) and they integrated them into those of the modern Athenian landscape and life (i.e., modern transportation systems and new buildings).

The link between Athens of the past with the contemporary one can be easier reflected through the palimpsest analogy (Khirfan, 2010). The rich history of Athens through the centuries can be reflected by various important periods that the city 
experienced (e.g., the Classical, Roman, Byzantine, or modern eras). The Olympics (through the main interventions they provided) gave the opportunity to the visitors to see the different levels of the city through time, in one environment, monitoring this way the differences in the centuries. For instance, the modern metro station/museum of Syntagma has been built in a form where people/passengers realise the various levels of the city's history through a glass window that shows traces of the past in the Athenian ground (e.g., a tomb, water-supply canals, etc.). This happens also in other stations such as the Monastiraki and Acropolis where artefacts/relics are exhibited. Moreover, the construction of the New Acropolis Museum has been planned appropriately in order for the visitors to be able to see the ancient settlement that the museum is built on through the glass floor, the temple of Parthenon through the glass walls of the museums, and at the same time, to admire the view of the modern city, the exquisite design of the museum itself, and the Olympic venues of the coast of Athens (Faliro Bay). Hence, the palimpsest analogy reflects the reshaping of Athens and the different layers of urban and historic order that were restructured with the Olympics giving the possibility to the city to project is uniqueness and authenticity.

\section{Cultural integration and multiculturalism}

According to ATHENS 2004 (2004, p. 49): ‘The Olympic Games in Greece have a special meaning because they combine modern infrastructure with unique, cultural and social aspects'. In particular, the organisation of the Athens' Olympic Games led Greece to initiate in all Greek school levels the Olympic Education programme prior the Games, which aimed to raise awareness about the values of Olympism by cultivating the spirit and culture of Olympic solidarity across the world. This programme taught students the history of the Olympics, the values of sports, the importance of the Olympics for Greece, the significance of volunteerism, and the role of exercise in health (Grammatikopoulos et al., 2005). The value of this programme lies not only in connecting the ancient Olympic heritage with the modern one but also providing a pedagogical tool for promoting the cultural integration of all the world's nations, which is a core aim of the Olympic Movement. 
In terms of culture, the Organising Committee focused on this aspect not only by providing for instance the ancient Panathinaiko Stadium (also the Olympic Stadium for 1896) for the sports of marathon and archery, but also by promoting two major initiatives: the Olympic Truce and the Cultural Olympiad (ATHENS 2004, 2004). The concept of the Olympic Truce aims to protect the interests of athletes and sports searching simultaneously for peaceful and diplomatic solutions for the recovery of the world's conflicts (IOC, 2008). As the IOC (2008, p. 2) states:

'In Athens, the Olympic Games -and the symbol of the Olympic Trucewent back to their country of origin. The Olympic Truce and UN flags were flown at the Olympic Village, and various events in support of the Olympic Truce took place’.

The second initiative, the Cultural Olympiad cost 120 million Euros and included over 100 high level performances and events in Greece and abroad (ATHENS 2004, 2004). The main theme of the Cultural Olympiad referred to the multicultural character of the Olympics that is also evident in the city, and had as a central message: 'Culture of Civilisations' (ATHENS 2004, 2004). Fauquembergue (2008) argues that the Organising Committee aimed to project the Greek element focusing for instance on Greek themes. The author states that $43 \%$ of the events of the Cultural Olympiad had to do with Hellenic subjects and the Organising Committee tried to link them with the spiritual and physical aspects of life.

Both of the above initiatives boosted the cultural characteristics of Athens and enriched its tangible and intangible heritage. In the case of Greece, the use of the past (through the projection of Hellenic themes) was incorporated with the ideals of Olympism and the global environment through arts, concerts and events, creating the unique motif of culture mentioned above. Furthermore, the emphasis on the multicultural character of the city became more evident: citizens of the world became one by joining and participating in the Games' celebration. Thus, apart from viewing the Olympics merely as an occasion for elevating a nation’s prestige, Traganou (2010) argued that the Games might be seen as opportunities for making visible alternative identities and 
renewed national narratives that stretch the conceptual boundaries of the nation and its relation with other nations.

However, in this case there is lack of continuity. As one respondent mentioned:

'Despite the happy atmosphere of the Olympic Athens, until today there have not been done many efforts for projecting the multi-cultural character of the city and its citizens. The city keeps promoting through the media, the negative aspects of this multi-cultural image (e.g., xenophobia, criminality, etc.) and leaves the presentation of the positive points, such as the exchange of different cultural elements out of the focus, creating an image for modern Athens and its historic centre, as a dangerous and inhospitable environment'.

Along the same lines, another respondent underlined:

'The opportunities that the Olympics brought to change the image of the city were not fully utilised. For example, visitors see in Athens only one element: the classical culture. Unfortunately, the modern culture of the city is not promoted at all'.

\section{The use of Athens' Olympic legacy and heritage in cultural tourism}

\section{Contribution of the Olympics to cultural tourism}

Athens' rich cultural deposits played a significant role in the formation of its tourism product (Khirfan, 2010; Papageorgiou-Venetas, 1996). The Games not only contributed by renovating and upgrading museums, archaeological sites, and public spaces of cultural significance in the city, but also brought a series of other popular art events through the organised efforts of Cultural Olympiad and the Olympic Truce. Additionally, many of the Olympic venues/facilities are now used (or they are intended to be used) for contemporary cultural performances. In this regard, venues such as the Badminton 
Theatre and the Faliro Pavilion give space to many state-of-the-art performances. However, according to a respondent: 'The utilisation of venues for enriching the tourism product of Athens is partial and has not been promoted adequately. Any development and promotion is of limited scale'.

Moreover, interventions that were either initiated or completed because of the Games contributed to the projection of Athens' cultural deposits. For instance, the improvement of the city's transportation system provided the opportunity to the visitors to move easier through the city (Singh and $\mathrm{Hu}, 2008$ ) and thus admire its cultural treasures, promoting this way the image of Athens as a contemporary cultural destination. Additionally, various metro stations operate as open museums facilitating the illustration of the palimpsest to passengers and contributing to the formation of a better cultural identity for the city that connects the past with the presence. Furthermore, the acceleration of the New Acropolis Museum's construction due to the Olympics (meant to be ready for the Games but due to bureaucratic constraints it was finally completed in 2008) (Secretariat General of Mass Media, 2010) is a milestone on the cultural tapestry of Athens, not only because it houses the Parthenon exhibits but also because by itself is a unique element of the city's contemporary architecture. As an official indicated: 'The Acropolis museum provides all the necessary technological advances, such as audiovisual appliances for communicating more effectively the history of the city. So it helps the promotion of the city's identity worldwide through cultural tourism'.

Overall, the legacy of the Olympics has been multidimensional and improved significantly the quality of life of the citizens and visitors of Athens in both functional and aesthetic aspects. The organisation of Olympics was one of the few attempts in the city's history for the holistic development of cultural tourism in Athens. In this respect, the Games represent an opportunity for bridging the various cultural elements of cities (i.e., of different eras and of various levels of significance) which, along with the supportive infrastructure, can regenerate and transform urban places into major cultural destinations. Similarly, they can also project their cultural identity to both visitors and residents. 


\section{Marketing the Olympic legacy}

As Asworth and Kavaratzis (2009, p. 521) state: 'Athens successfully hosted the Olympic Games of 2004 and is now anxiously anticipating their positive effects inviting you to “surprise yourself in Athens Attica”'. However, the collective efforts for promoting cultural tourism in Athens during 2004 did not continue during the following years. In contrast, any attempt was sporadic and not based on a comprehensive cultural tourism plan. As a respondent stated:

'The Games had a great impact on tourists in Athens because they gave them the opportunity to see and participate in various cultural events and festivals. However, this happened only during the Olympics. After that period tourism in Athens has fallen. People visit Athens just to see the Acropolis. The other cultural features of the city are not promoted at all to the international travellers'.

Another respondent mentioned that the utilisation of the Olympic venues in terms of management and marketing is problematic. The official stated:

'You need to exploit the heritage of the Olympic Games and to promote it. This was not done until now. You have a great infrastructure but you do not project it. The reason that this is happening is the lack of money and the inappropriate management of the Olympic legacy. Maybe it will happen in the future'.

Obviously, the recent economic crisis that now infests the country and the several problems (e.g., social concerns, immigration, etc.) that this crisis brings do not provide the appropriate conditions for the effective management of the Olympic legacy. However, this does not invalidate the potential for utilisation of the Olympic legacy and its integration into the city's overall tourism product. On the contrary, it calls for the need 
to develop a strategic framework for leveraging the Olympic legacy of Athens and overcoming the inherent problems.

Moreover, the Olympics created a unique context where visitors had the chance to participate in various cultural events and thus gave an impetus for interaction among different nationalities and exchange of ideas. However, again in this case not many attempts have been made in the years after the Olympics to promote the multicultural character that was projected during the Games. According to an official:

'During the Games the city had a unique chance to show its real self to other cultures. There were people all over the city. Today this happens in only some places, probably the city centre. The other areas of Athens are hidden; only the residents know them. Tourists see only Monastiraki and Plaka [central areas of Athens] and the Greece of 1960s'.

The above statements indicate the lack of strategic marketing planning in the postOlympic era for the development of cultural tourism. Athens is a city with a multicultural character but the image of the city today is completely different from that of Athens in 2004. This image incongruity in combination with the city’s inefficient marketing management, are important issues that need to be addressed by the tourism policy. Therefore, it is imperative to develop a strategic tourism planning framework and find the best means to use the Olympic legacy as a leverageable resource.

\section{A framework for leveraging post-Games Olympic tourism}

The recent advances in the study of event leverage can serve as a basis to develop a strategic planning framework for leveraging Olympic-related tourism in the post-Games period. In this regard, O’Brien and Chalip (2008) in elaborating the general models of economic and social leverage of sport events noted the synergies that exist between economic and social leverage and the potential for developing new forms of leverage, which arise from the policy purposes and the creation of synergies in a host city. As such, 
the cultivation of Olympic heritage and subsequent development of cultural heritage tourism represents an opportunity that needs to be leveraged in synergy with the sportrelated structures and elements of the Olympics. In other words, this constitutes a new form of post-event leverage that involves the cross-leveraging of sport, heritage, culture, and tourism assets.

In this respect, based on Chalip’s (2004) general event leveraging model and Weed's (2008) Olympic tourism leveraging model, a strategic planning framework is proposed for leveraging post-Games Olympic tourism as shown in Figure 2. In the years following the Olympics, the two opportunities for leverage are the legacy of the Games and its effects on the cultural heritage of the host city. As such, an Olympic host city may choose to capitalise on its Olympic legacy and rich heritage assets. This requires the implementation of synergistic cross-leveraging strategies aimed at optimising sportrelated and cultural-related tourism benefits. These strategies can encompass the manifold dimensions of Olympic heritage while enriching the city's tourism product by integrating its sport and cultural tourism offerings.

[Figure 2]

In order to attain these joint strategic objectives, there are two grounding strategies, which constitute the ground for further strategies and actions to be employed. The first grounding strategy is to utilise the Olympic venues for organising events and activities. This takes advantage of the structures built for the Olympics and the associated prestige embodied in the collective memory from previously having hosted events in the Olympics. The second grounding strategy is the use of Olympic legacy and heritage themes in media (advertising and promotion) to reinforce destination images. This is because as time progresses after the hosting of Olympics, the Games gradually become a part of the destination profile. Thus, the hosting of the Olympics should be used to promote the attributes of the destination in the post-Games period. As such, a host city's Olympic association sets should be transferred to its destination image. For example, the top quality sports along with the successful organisation of the Games can be linked and 
transferred to high-quality tourism products and services, or the modern infrastructure of the Olympics can be transferred to create the image of a modern and efficient Athens.

Based on the grounding strategies, there are a number of derivative strategies that can be implemented to enrich an Olympic host city's tourism product. In particular, an Olympic host city by capitalising on both the Olympic legacy and the range of cultural heritage assets, can design Olympic-related attractions (e.g., easier access to the city coast, theme/natural parks, Olympic museum, etc.), develop a portfolio of sport and cultural events, package sport and cultural attractions, and attract conferences/exhibitions in the Olympic venues. These strategies can sustain the value of Olympic legacy incorporated in the development of cultural heritage tourism, transferring thus the 'glory' of the Olympics to the attractions, events, and conferences/exhibitions of the city's tourism product mix.

The proposed post-Games leveraging framework can be applied and tested on different Olympic host cities in order to validate it as a prescriptive tool for fostering planned legacies and cross-leveraging initiatives. The applicability of the framework to the case of Athens is constrained by the severe economic crisis the city (and Greece) currently deals with. It has to be recognised, however, that the crisis is mainly the result of chronic structural pathogenies and deficiencies of the Greek administrative and political system (Alexiou, 2011; Kouretas and Vlamis, 2010). The changes and restructuring that are under way may facilitate the development and implementation of leveraging initiatives. To do so, Athens' tourism policy should incorporate leveraging programs into its immediate plans and invest to the Olympic legacy and cultural tourism in its effort to restore the city's shattered economy. It is suggested as this paper showed that despite many years passed after the Games it is still not very late as Athens' Olympic heritage is inexhaustible and as such will always have strong connections with the Games due to its ancient routes as well as the first modern Games. 


\section{Concluding remarks}

The case of Athens is an example of transforming an overcrowded capital with significant cultural elements into a modernised European city. The Olympic Games helped to the recovery of Athens' image and endowed it not only with great sport venues and facilities, but also with upgrades and improvements of infrastructure, tourism superstructure and cultural features. Thus, the Games stimulated international interest in the city for the second time in the modern history and enhanced its tourism industry.

In decoding the meaning of the Olympics and its contribution to the multifaceted representation and reconstruction of Athens' cultural heritage it appears that the Games epitomised the need both for continuity and change by encompassing competing 'glocal' forces in the discourse of cultural homogenisation or global heterogeneity. This means that the Olympics did not merely elevate Athens’ prestige or status, but they also contributed to the expansion of its cultural tapestry portraying -though implicitly- aspects of a diverse ethnoscape emerging globally. In essence, the multifaceted representation and reconstruction of Athens' identity and heritage have bolstered the legacy of the Games, which affords Athens the possibility to capitalise upon in the post-Games period.

Despite the persistent problems, there is a significant chance for Athens to develop and enrich cultural tourism by leveraging its Olympic legacy in synergy with its heritage in order to offer visitors a variety of experiences and activities. In doing so, Athens should recognise that its Olympic heritage needs to be leveraged in ways that its historic and contemporary tourism attractions reflect and reproduce place identity and place attachment of residents. This requires understanding Athens' palimpsest through the layers of historical and urban order and, in turn, promoting the subsequent different facets of Athens' heritage to foster cultural tourism.

The findings of this study contribute to the literature by providing an analysis of the interrelationship between Olympic legacy and cultural tourism as shaped by the representation, reconstruction and use of heritage. The core issue in this analysis is how to develop cross-leveraging synergies between the Olympic Games legacy and cultural heritage tourism for the host city. The tourism-oriented literature tends to focus on the effects of the Olympics either on sport or on tourism in general without fully examining a 
host city's heritage, identity and the subsequent potential to develop cultural tourism. In this regard, this study sheds light on the nature, salience and complexity of Olympic heritage. Overall, by examining the interrelationship between Athens' Olympic legacy, heritage and the city's development of cultural tourism, this study adds another dimension that reveals the multi-layered interrelations between sport, heritage, culture, and tourism and their potential for synergistic cross-leverage. 


\section{References}

Alexiou, C., 2011. "When the bough breaks": making sense of the Greek economic 'Waterloo'. International Journal of Economic and Financial Issues, 1(3), 123-132.

Ashworth, G.J and Kavaratzis, M., 2009. Beyond the logo: brand management for cities. Journal of Brand Management, 16(8), 520-531.

Ashworth, G.J. and Tunbridge, J.E., 1990. The tourist-historic city. London: Belhaven Press.

Asprogerakas, E., 2007. City competition and urban marketing: the case of tourism industry in Athens. Tourismos, 2(1), 89-114.

ATHENS 2004, 2004. In the true spirit of the Games [online], Athens 2004. Available from: http://multimedia.olympic.org/pdf/en_report_897.pdf [Accessed 4 February 2011].

Avgerinou-Kolonia, S., 2000. Spatial dynamics of tourism in Greece. Minutes from the Meeting of Panteios-CNRS. Available from:

http://postgrasrv.hydro.ntua.gr/gr/edmaterial/education/avgerinou/Xorikes_dynamik es.pdf [Accessed 18 May 2011].

BBC, 2004. Olympics 2004 [online]. BBC Sport. Available from: http://news.bbc.co.uk/sport2/hi/olympics_2004/default.stm [Accessed 4 February 2011].

Beriatos, E., 2006. Athens: the transformation of a Mediterranean metropolis. Problems and perspectives after Olympics 2004 [online]. Paper presented at the ISoCaRP Congress, Istanbul, Turkey. Available from: http://www.isocarp.net/Data/case_studies/797.pdf [Accessed 15 September 2010].

Beriatos, E. and Gospodini, A., 2004. "Glocalising" urban landscapes: Athens and the 2004 Olympics. Cities, 21(3), 187-202.

Boniface, B.G. and Cooper, C., 2005. Worldwide destinations: the geography of travel and tourism. 4th ed. Oxford: Elsevier Butterworth-Heinemann.

Brown, G., et al., 2004. Developing brand Australia: examining the role of events. In: N. Morgan, A. Pritchard and R. Pride, eds. Destination branding: creating the unique destination proposition. 2nd ed. Oxford: Elsevier Butterworth-Heinemann, 279-305.

Burbank, M.J., Andranovich, G., and Heying, C.H., 2001. Olympic dreams: the impact of mega-events on local politics. Boulder, CO: Lynne Rienner.

Cartalis, C., 2003. Athens 2004: The legacy. Olympic Review. Available from: http://www.la84foundation.org/OlympicInformationCenter/OlympicReview/2003/ OREXXVIII49/OREXXVIII49s.pdf [Accessed 4 February 2011].

Chalip, L., 2004. Beyond impact: a general model for sport event leverage. In B.W. Ritchie and D. Adair, eds. Sport tourism: interrelationships, impacts and issues. Clevedon: Channel View, 226-252.

Chalip, L., 2006. Towards social leverage of sport events. Journal of Sport \& Tourism, 11(2), 109-127.

Crang, M., 1996. Envisioning urban histories: Bristol as palimpsest, postcards, and snapshots. Environment and Planning, 28(3), 429-452. 
Creswell, J. W., 2006. Qualitative inquiry and research design: choosing among five traditions. 2nd ed. London: Sage.

Dagli, C., 1998. Olympic Games 2004: positive and negative impacts on tourism. Technical Chamber of Greece. Available from: http://library.tee.gr/digital/m1861/m1861_dagli.pdf [Accessed 4 February 2011].

Dansero, E. and Puttilli, M., 2010. Mega-events tourism legacies: the case of the Torino 2006 Winter Olympic Games - a territorialisation approach. Leisure Studies, 29(3), 321-341.

Denzin, N.K. and Lincoln, Y.S., 2005. Introduction: the discipline and practice of qualitative research. In: N.K. Denzin and Y.S. Lincoln, eds. Handbook of qualitative research. Thousand Oaks, CA: Sage, 1- 42.

Derrett, R., 2004. Festivals, events and the destination. In: I. Yeoman et al., eds. Festival and events management: an international arts and culture perspective, Oxford: Butterworth-Heinemann, 32-52.

EL.STAT., 2003. Total nights spent at tourist lodging facilities per prefecture 2003. Hellenic Statistical Authority. Available from: http://www.statistics.gr/portal/page/portal/ESYE/BUCKET/A2001/Other/A2001_S TO12_TB_MM_00_2003_05_F_GR.pdf [Accessed 18 May 2011].

EL.STAT., 2005. Total nights spent at tourist lodging facilities per prefecture 2005. Hellenic Statistical Authority. Available from: http://www.statistics.gr/portal/page/portal/ESYE/BUCKET/A2001/PressReleases/A 2001_STO12_DT_MM_00_2005_01_F_GR.pdf [Accessed 18 May 2011].

EL.STAT., 2007. Total nights spent at tourist lodging facilities per prefecture 2007. Hellenic Statistical Authority. Available from: http://www.statistics.gr/portal/page/portal/ESYE/BUCKET/A2001/PressReleases/A 2001_STO12_DT_MM_00_2007_01_F_GR.pdf [Accessed 18 May 2011].

EL.STAT., 2009. Total nights spent at tourist lodging facilities per prefecture 2009. Hellenic Statistical Authority. Available from: http://www.statistics.gr/portal/page/portal/ESYE/BUCKET/A2001/PressReleases/A 2001_STO12_DT_MM_00_2009_01_P_GR.pdf [Accessed 18 May 2011].

Essex, S. and Chalkley, B., 1998. Olympic Games: catalyst of urban change. Leisure Studies, 17(3), 187-206.

Eisenhardt, K.M., 1989. Building theories from case study research. Academy of Management Review, 14(4), 532-550.

Eisenhardt, K.M. and Graebner, M.E., 2007. Theory building from cases: opportunities and challenges. Academy of Management Journal, 50(1), 25-32.

European Commission Citizenship, 2005. National Report - Greece. Study on Volunteering in the European Union Country Report Greece. Available from: http://ec.europa.eu/citizenship/eyv2011/doc/National\%20report\%20GR.pdf [Accessed 4 February 2011].

Fauquembergue, M., 2008. The Cultural Olympiad of the Olympic Games Athens 2004 past and modern Olympic values expressed through artistic events and cultural exchange. Kurzfassungen der Vorträge Mainzer Sport-Studenten auf dem vorolympischen Wissenschaftskongress, Guangzhou, China. Available from: http://www.sport.uni-mainz.de/mueller/Guangzhou08/5MarcAbstr08.pdf [Accessed 4 February 2011]. 
Feloukatzi, H., 2004. Take off your hat to the Greeks [online]. Eleftherotypia, 16 August, Available from:

http://archive.enet.gr/online/online_text/c=112,dt=16.08.2004,id=59089340

[Accessed 25 February 2011].

Gammon, S. and Ramshaw, G., eds., 2007. Heritage, sport and tourism: sporting paststourist futures. London: Routledge.

Greek General Secretariat of Sports, 2011. Peace and Friendship Stadium [online]. Ministry of Culture and Tourism Development. Available from: http://www.sefstadium.gr/ [Accessed 4 February 2011].

Gold, M.M. and Revill, G., 2011. The Cultural Olympiads: reviving the panegyris. In: J.R. Gold and M.M. Gold, eds. Olympic cities: city agendas, planning, and the World's Games, 1896-2016. 2nd ed. Abingdon, Oxon: Routledge, 80-107.

Gold, M.M., 2011. Athens 2004. In: J.R. Gold and M.M. Gold, eds. Olympic cities: city agendas, planning, and the World's Games, 1896-2016. 2nd ed. Abingdon, Oxon: Routledge, 315-339.

Gold, J.R. and Gold, M.M., eds., 2011. Olympic cities: city agendas, planning, and the World's Games, 1896-2016. 2nd ed. Abingdon, Oxon: Routledge.

Gospodini, A., 2009. Post-industrial trajectories of Mediterranean European cities: the case of post-Olympic Athens. Urban Studies, 46(5/6), 1157-1186.

Grammatikopoulos, V., Tsigilis, N., Koustelios, A., and Theodorakis, Y., 2005.

Evaluating the implementation of an Olympic Education Program in Greece.

International Review of Education, 51(5/6), 427-438.

Gratton, C. and Preuss, H., 2008. Maximizing Olympic impacts by building up legacies. The International Journal of the History of Sport, 25(14), 1922-1938.

Hiller, H.H., 1998. Assessing the impacts of mega-events: a linkage model. Current Issues in Tourism, 1(1), 47-57.

Hiller, H.H., 2006. Post-event outcomes and the post-modern turn: the Olympics and urban transformations. European Sport Management Quarterly, 6(4), 317-332.

Horne, J., 2007. The four 'knowns' of sports mega-events. Leisure Studies, 26(1), 81-96.

Irish Tourist Board, 1988. Inventory of cultural tourism resources in the member states and assessment of methods used to promote them. DG VII, European Commission, Brussels.

IOC, 2008. Factsheet: Olympic Truce, International Olympic Committee, [online], 28 July. Available from: http://multimedia.olympic.org/pdf/en_report_839.pdf [Accessed 25 February 2011].

Jenkins, S., 2004. Let's give these Games a gold medal [online]. Washington Post, 30 August, Available from: http://www.washingtonpost.com/wp-dyn/articles/A451352004Aug29.html [Accessed 1 February 2011].

Karkatsoulis, P., Michalopoulos, N., and Moustakatou, V., 2005. The national identity as a motivational factor for better performance in the public sector: the case of the volunteers of the Athens 2004 Olympic Games. International Journal of Productivity and Performance Management, 54(7), 579-594.

Kissoudi, P., 2008. The Athens Olympics: optimistic legacies - post-Olympic assets and the struggle for their realization. International Journal of the History of Sport, 25(14), 1972-1990. 
Kitroeff, A., 2004. Wrestling with the ancients: modern Greek identity and the Olympics. New York: Greekworks.Com Inc.

Khirfan, L., 2010. Traces on the palimpsest: heritage and the urban forms of Athens and Alexandria. Cities, 27(5), 315-325.

Kostof, S., 1991. The city shaped: urban patterns and meanings through history. New York: Bulfinch Press.

Kouretas, G.P. and Vlamis, P., 2010. The Greek crisis: causes and implications. PANOECONOMICUS, 4, 391-404.

Koutoulas, D., et al., 2009. Understanding the tour operators' point of view for effectively marketing a tourism destination: the case of Athens, Tourism Today, 9, 65-77.

MacAloon, J.J., 1984. Olympic Games and the theory of spectacle in modern societies. In J. J. MacAloon, ed. Rite, drama, festival, spectacle: rehearsals toward a theory of cultural performance. Philadelphia, PA: Institute for the Study of Human Issues, Inc, 241-280.

Maloutas, T., Sayas, J., and Souliotis, N., 2009. Intended and unintended consequences of the 2004 Olympic Games on the sociospatial structure of Athens [online]. Paper presented at the 2009 ISA-RC21 Sao Paulo Conference: Inequality, Inclusion and the Sense of Belonging. Available from: http://isocarp.ch/events/2009/sayas21.pdf [Accessed 10 May 2011].

Mangan, J.A. and Dyreson, M., eds., 2009. Olympic legacies: intended and unintended political, cultural, economic and educational. London: Routledge.

Miles, M. and Huberman, A., 1994. Qualitative data analysis. 2nd ed. London: Sage.

Milionis, S., 2010. City marketing in Greece: the post-Olympic use of Hellinikon Former Airport Site. Regional Science Inquiry Journal, 2(2), 151-172.

Municipality of Peristeri, 2010. National championship and cup for chess: 3-10 July at the renovated Olympic facilities of Peristeri [online]. Municipality of Peristeri News. Available from: http://www.peristeri.gr/index.php?option=com_contentandtask=viewandid=1177an dItemid=185 [Accessed 4 February 2011].

OAKA, 2011. Sport facilities [online]. Olympic Athletic Centre of Athens 'Spiros Louis'. Available from: http://www.oaka.com.gr/default.asp?e_lang_id=1 [Accessed 4 February 2011].

O’Brien, D., 2006. Event business leveraging: the Sydney 2000 Olympic Games. Annals of Tourism Research, 33(1), 240-261.

O’Brien, D. and Chalip, L., 2008. Sport events and strategic leveraging: pushing towards the triple bottom line. In: A. Woodside and D. Martin, eds. Tourism management: analysis, behaviour and strategy. Oxfordshire: CAB International, 318-338.

Olympicvillagenews, 2011. Olympic Village: about the residents [online]. The Athens Olympic Village News. Available from: http://www.olympicvillagenews.gr/olympic-village [Accessed 4 February 2011].

Olympic Properties, 2008. The course of post-Olympics use of the Olympic Properties. News and Press Conferences, 12 June. Available from: http://www.olympicproperties.gr/contents_gr.asp?id=317andprnt=1 [Accessed 4 February 2011]. 
Papageorgiou-Venetas, A., 1996. Tourism development of monuments and cultural places in Athens or the inbound of inflow of tourists in Athens and its consequences in the historical buildings of the city. Archaeology and Arts, 61, 97-103.

Parnitha National Park, 2011. Mountain Biking [online]. Prefecture of Attica, Forest Inspection of Parnitha. Available from: http://www.parnithanp.gr/oreini_podilasia.htm [Accessed 4 February 2011].

Potsiou, C.A. and Zentelis, P., 2005. Greece after the Gold Rush: land development impact analysis and sustainability of the 2004 Olympic infrastructure. Paper presented at the Pharaohs to Geoinformatics conference, 16-21 April 2005 Cairo, Egypt.

Preuss, H., 2007. The conceptualisation and measurement of mega sport event legacies. Journal of Sport \& Tourism, 12(3/4), 207-228.

Prime Minister's Press Office, 2005. Greetings of K. Karamanlis for the opening of the Olympic Village's Polyclinic, 28 July. Available from: http://www.ana.gr/anaweb/user/showprel?service=3andmaindoc $=3188820$ [Accessed 4 February 2011].

Ramshaw, G., 2010. Living heritage and the sports museum: athletes, legacy and the Olympic Hall of Fame and Museum, Canada Olympic Park. Journal of Sport \& Tourism, 15(1), 45-70.

Ramshaw, G. and Gammon, S., 2010. On home ground? Twickenham stadium tours and the construction of sport heritage. Journal of Heritage Tourism, 5(2), 87-102.

Richards, G., 1996. Production and consumption of European cultural tourism. Annals of Tourism Research, 23(2), 261-283.

Ritchie, J.R.B., 2000. Turning 16 days into 16 years through Olympic legacies. Event Management, 6(3), 155-165.

Roche, M., 2000. Mega-events and modernity: Olympics, expos and the growth of global culture. London: Routledge.

Secretariat General of Mass Media, 2010. The foreign mass media for the transportation of the antiquities to the New Museum of Acropolis [online]. Secretariat General of Communication and Information. Available from: http://www.minpress.gr/minpress/en/index/information/information_xena_mme_me tafora_arxaiotitwn.htm [Accessed 14 September 2011].

Serraos, K., Ioannou, B., and Papaioannou, A., 2007. The generation of urban poles of interest on the occasion of great events and interventions: Athens - Hamburg a comparative approach. AESOP2007, Napoli, Italy.

Siggelkow, N., 2007. Persuasion with case studies. Academy of Management Journal, 50(1), 20-24.

Singh, N. and Hu, C., 2008. Understanding strategic alignment for destination marketing and the 2004 Athens Olympic Games: implications from extracted tacit knowledge. Tourism Management, 29(5), 929-939.

Stadia, 2011. Olympic Games 2004 [online]. Olympic Athletic Centre of Athens. Available from: http://www.stadia.gr/oaka/oaka-f-gr.html [Accessed 4 February 2011].

Sykianaki, C., 2003. Athens and Olympic Games 2004 [online]. Organization for Planning and Environmental Protection of Athens. Report on the Findings and Conclusions of the Torino meeting of the METREX Expert Group on Planning for 
Major Events. Available from:

http://www.eurometrex.org/Docs/Expert_Groups/Major_Events/Torino_Report_20 03.pdf [Accessed 15 October 2010].

Sykianaki, C., 2006. Strategic program for post-Olympic Athens sustainable development. Athens: Organisation for Planning and Environmental Protection of Athens.

Traganou, J., 2008. Shades of blue: debating Greek identity through Santiago Calatrava's design for the Athens Olympic Stadium. Journal of Modern Greek Studies, 26(1), 185-214.

Traganou, J., 2009. National and post-national dynamics in the Olympic design: the case of the Athens 2004 Olympic Games. Design Issues, 25(3), 76-91.

Traganou, J., 2010. National narratives in the Opening and Closing Ceremonies of the Athens 2004 Olympic Games. Journal of Sport \& Social Issues, 34(2), 236-251.

Travlou, P., 2006. Go Athens: a journey to the centre of the city. In: S. Coleman and M. Crang, eds. Tourism: between place and performance. New York: Berghahn Books, 108-127.

Tsartas, P., Koutoulas, D., and Papathedorou, A., 2008. Situational study of Athenian tourism - from pre-Olympic to post-Olympic period: The impacts of Olympic Games on the Athenian tourism and the current situation, strategic priorities, potential-challenges and the actions for the next pentad[online]. Company of Tourist and Economic Development of Athens. Available from:

http://www.atedco.gr/files/meleti-athinaikou-tourismou.pdf [Accessed 4 October 2010].

Tyler, N., 2000. Historic preservation: an introduction to its history, principles, and practice. 2nd ed. New York: Norton.

Tziralis, G., et al., 2006. Economic aspects and sustainability impact of the Athens 2004 Olympic Games. In: K. Arravosis, et al., eds. Environmental economics and investment assessment. Southampton: WIT Press, 21-33.

Waitt, G., 2003. Social impacts of the Sydney Olympics. Annals of Tourism Research, 30(1), 194-215.

Weed, M., 2008. Olympic tourism. Oxford: Butterworth-Heinemann.

Yin, R.K., 2009. Case study research: design and methods. 4th ed. Thousand Oaks, CA: Sage.

Zagorianakos, E., 2004. Athens 2004 Olympic Games’ transportation plan: a missed opportunity for strategic environmental assessment (SEA) integration? Journal of Transport Geography, 12(2), 115-125.

Zentelis, P. and Labropoulos, T., 2004. The impact of Athens 2004 Olympic Games on property price in Greece. Journal of Property Tax Assessment and Administration, $1(3), 5-20$.

Zifou, M. et al., 2004. The 2004 Olympic Games: a non-planning paradigm? [online]. Paper presented at the AESOP congress, Grenoble, France. Available from: https://courses.arch.ntua.gr/fsr/112805/AESOP_04.pdf [Accessed 15 September 2010].

Zografos, G. and Deffner, A., 2007. How does a mega event affect the hosting country's tourism development: the case of Greece and the 2004 Olympics. Discussion Paper Series, 13(14), 333-348. 
Table 1: Venues and Facilities of Athens 2004 - Current and Future Use

\begin{tabular}{|c|c|c|c|}
\hline & Venue/Facility & Use in 2004 & Current use/Suggested use \\
\hline 1 & $\begin{array}{l}\text { Agios Kosmas Sailing } \\
\text { Centre }\end{array}$ & -Sailing & $\begin{array}{l}\text {-Long-term rental to the company Serios S.A. in } 2007 \text { for being a Mar } \\
\text { and large terrestrial coastal development, which will provide a major } \\
\text { new tourist portal of Attica. }\end{array}$ \\
\hline 2 & Ano Liosia Arena & -Judo, Wrestling & $\begin{array}{l}\text {-Future establishment of Cultural Academies. Until then it is rented } \\
\text { (short-term). }\end{array}$ \\
\hline \multirow[t]{8}{*}{3} & Faliro Bay Complex & & \\
\hline & Faliro Pavilion & $\begin{array}{l}\text {-Taekwondo, } \\
\text { Volleyball }\end{array}$ & $\begin{array}{l}\text {-Commercial operation and utilisation of the venue as an International } \\
\text { Conference Centre. The stage of pres-selecting candidates is complete }\end{array}$ \\
\hline & $\begin{array}{l}\text { Olympic Beach } \\
\text { Volleyball }\end{array}$ & -Beach Volleyball & $\begin{array}{l}\text {-A long-term contract has been signed with the company SK } \\
\text { Pazaropoulos SA in } 2007 \text {. The venue will be shaped to serve the needs } \\
\text { of multi-purpose auditorium to conduct cultural and sporting events. }\end{array}$ \\
\hline & $\begin{array}{l}\text { Area between the outfalls } \\
\text { of Ilisos and Kifisos } \\
\text { Rivers } \\
\text { Southeast edge of Faliro }\end{array}$ & -Open area & -Will be converted into open sport facilities and an ecological park. \\
\hline & $\begin{array}{l}\text { Pole (between area of } \\
\text { Tae Kwon Do and } \\
\text { Marina of Floisvos }\end{array}$ & -Open area & $\begin{array}{l}\text {-Turned over to the Municipality of Palaio Faliro for conversion into } \\
\text { green spaces, kinder-garden, and athletic facilities. }\end{array}$ \\
\hline & $\begin{array}{l}\text { Nautical/Athletic Marina } \\
\text { of Floisvos }\end{array}$ & -Open area & $\begin{array}{l}\text {-Turned over to the Greek Sailing Federation through a signed } \\
\text { Agreement in 2006. It is used as a National Nautical/Athletic Centre } \\
\text {-The first Olympic Stadium of the Modern Olympic Games in } 1896 \text { is }\end{array}$ \\
\hline & Panathinaiko Stadium & -Marathon, Archery & $\begin{array}{l}\text { used as an attraction and is open to visitors daily. It is used also for } \\
\text { concerts and sporting events. }\end{array}$ \\
\hline & $\begin{array}{l}\text { Peace and Friendship } \\
\text { Stadium }\end{array}$ & -Volleyball & $\begin{array}{l}\text {-Used for indoor sports (i.e., basketball, volleyball, etc.) and as a conc } \\
\text { and exhibition hall. }\end{array}$ \\
\hline 4 & $\begin{array}{l}\text { Galatsi Arena/Galatsi } \\
\text { Olympic Hall }\end{array}$ & $\begin{array}{l}\text {-Table tennis, } \\
\text { Rhythmic Gymnastics }\end{array}$ & $\begin{array}{l}\text {-Long-term rental (40 years) to Acropol Haragionis S.A. and Sonae } \\
\text { Sierra SGPS S.A. in 2006. It is being converted to a shopping mall an } \\
\text { retail/entertainment/sports centre. }\end{array}$ \\
\hline \multirow[t]{3}{*}{5} & Goudi Complex & & \multirow{3}{*}{$\begin{array}{l}\text {-Long-term rental to ABCD Company in 2006. The venue has been } \\
\text { retrofitted into the modern Badminton Theatre, hosting major theatric } \\
\text { productions and spectacles. }\end{array}$} \\
\hline & Equestrian Centre & -Equestrian & \\
\hline & Badminton & -Badminton & \\
\hline \multirow[t]{6}{*}{6} & Hellinikon Complex & & \\
\hline & $\begin{array}{l}\text { Hellinikon Olympic } \\
\text { Indoor Arena }\end{array}$ & $\begin{array}{l}\text {-Basketball, Handball, } \\
\text { Fencing }\end{array}$ & $\begin{array}{l}\text {-Used as a basketball field by a team of First Category and it is also re } \\
\text { (short-term) for conferences, exhibitions, and concerts. }\end{array}$ \\
\hline & $\begin{array}{l}\text { Hellinikon Hockey } \\
\text { Centre }\end{array}$ & -Field Hockey & \multirow{2}{*}{$\begin{array}{l}\text {-The venues are used for concerts. Other uses for the future include: } \\
\text { auxiliary spaces sporting uses, cultural events, restaurants. }\end{array}$} \\
\hline & $\begin{array}{l}\text { Hellinikon Softball } \\
\text { Stadium }\end{array}$ & -Softball & \\
\hline & $\begin{array}{l}\text { Hellinikon Baseball } \\
\text { Centre }\end{array}$ & -Baseball & -Used by Ethnikos Piraeus F.C. (Football Team) as a home field. \\
\hline & $\begin{array}{l}\text { Hellinikon } \\
\text { Canoe/Kayak/Slalom }\end{array}$ & -Canoe/Kayak & $\begin{array}{l}\text {-Long-term rental to the company Hellinikon Entertainment and Sport } \\
\text { Parks S.A. in 2006. The venue will be transformed into a sport centre } \\
\text { (partially already operated), water park, and theme park. }\end{array}$ \\
\hline 7 & $\begin{array}{l}\text { International Broadcast } \\
\text { Centre (IBC) }\end{array}$ & $\begin{array}{l}\text {-International } \\
\text { Broadcast Centre }\end{array}$ & $\begin{array}{l}\text {-Long-term rental to Lamda Development in 2006. Already used as a } \\
\text { commercial centre (shopping, retail, office and entertainment complex } \\
\text { (Golden Hall). Future use includes the construction of the Hellenic } \\
\text { Olympic Museum and the International Museum of Classical Athletic } \\
\text { by the Ministry of Culture (now Ministry of Culture and Tourism } \\
\text { Development). }\end{array}$ \\
\hline 8 & Karaiskaki Stadium & -Football & $\begin{array}{l}\text {-Used by Olympiacos FC (Football Team) and the Greek National } \\
\text { Football Team as a home field. Also used for concerts. }\end{array}$ \\
\hline 9 & Main Press Centre & -Main Press Centre & -Converted to the headquarters of the Ministry of Health and Social \\
\hline
\end{tabular}




\begin{tabular}{|c|c|c|c|}
\hline & (MPC) & & Solidarity of Greece. \\
\hline 10 & Olympic Village & Housing & -Apartments for residential use. The village hosts 11,000 citizens. \\
\hline 11 & $\begin{array}{l}\text { Markopoulo Shooting } \\
\text { Centre }\end{array}$ & -Shooting & $\begin{array}{l}\text {-Will be converted to the New Operations Training Centre of the Spec } \\
\text { Forces (Hellenic Police). }\end{array}$ \\
\hline 12 & $\begin{array}{l}\text { Markopoulo } \\
\text { Equestrian Centre }\end{array}$ & -Equestrian & $\begin{array}{l}\text {-Converted to the Hellenic Equestrian Federation and is rented by } \\
\text { various organisations and federations for worldwide range races. }\end{array}$ \\
\hline 13 & Nikea Arena & -Weightlifting & $\begin{array}{l}\text {-Turned over to the University of Piraeus for the needs of the Tertiary } \\
\text { Education. }\end{array}$ \\
\hline 14 & $\begin{array}{l}\text { Olympic Athletic } \\
\text { Centre of Athens } \\
\text { (OAKA) }\end{array}$ & & \\
\hline & Main Olympic Stadium & $\begin{array}{l}\text {-Opening and Closing } \\
\text { Ceremonies } \\
\text {-Track, Football }\end{array}$ & $\begin{array}{l}\text {-Used by Panathinaikos FC (Football Team), AEK FC (Football Team } \\
\text { and the Greek National Football Team as a home field, International } \\
\text { Football/Track/Fields competitions and concerts. }\end{array}$ \\
\hline & $\begin{array}{l}\text { Olympic Indoor Sports } \\
\text { Centre }\end{array}$ & $\begin{array}{l}\text {-Basketball, } \\
\text { Gymnastics, } \\
\text { Trampoline } \\
\text {-Swimming, Water }\end{array}$ & $\begin{array}{l}\text {-It hosts sporting events, concerts, conferences and other functions suc } \\
\text { as Motocross competitions. }\end{array}$ \\
\hline & Olympic Aquatic Centre & $\begin{array}{l}\text { Polo, Synchronised } \\
\text { Swimming, Diving }\end{array}$ & -Public pool and organisation of several swimming events. \\
\hline & Olympic Tennis Centre & -Tennis & -Tennis events (domestic and international). \\
\hline & Olympic Velodrome & -Cycling & -Cycling meets (domestic and international). \\
\hline 15 & $\begin{array}{l}\text { Parnitha Olympic } \\
\text { Mountain Bike Venue }\end{array}$ & -Mountain Biking & -Belong to the Parnitha National Park. Offered for mountain biking. \\
\hline 16 & $\begin{array}{l}\text { Peristeri Olympic } \\
\text { Boxing Hall }\end{array}$ & -Boxing & $\begin{array}{l}\text {-Renamed into the Olympic Indoor Hall. Used for chess games. It also } \\
\text { houses the Municipal Company of Cultural Development of Peristeri } \\
\text { Municipality. }\end{array}$ \\
\hline 17 & Schinias Rowing Centre & -Rowing, Canoeing & $\begin{array}{l}\text {-Will be converted to the National Training Centres of FISA } \\
\text { (International Rowing Federation) according to agreement in 2007. W } \\
\text { be one of the three training centres worldwide (after Munich and } \\
\text { Seville). }\end{array}$ \\
\hline 18 & $\begin{array}{l}\text { Vouliagmeni Olympic } \\
\text { Centre }\end{array}$ & -Triathlon & -Temporary Construction. Not currently existing. \\
\hline \multicolumn{4}{|c|}{$\begin{array}{l}\text { Sources: BBC (2004); General Secretariat of Sports (2011); Maloutas et al.(2009); } \\
\text { Municipality of Peristeri (2010); Olympcivillagenews (2011); Olympic Athletic Centre of } \\
\text { Athens (2011); Olympic Properties (2008); Parnitha National Park (2011); Serraos et al. } \\
\text { (2007); Stadia (2011); Sykianaki (2003) }\end{array}$} \\
\hline
\end{tabular}


Figure 1: Total nights spent at Attica's tourist lodging facilities

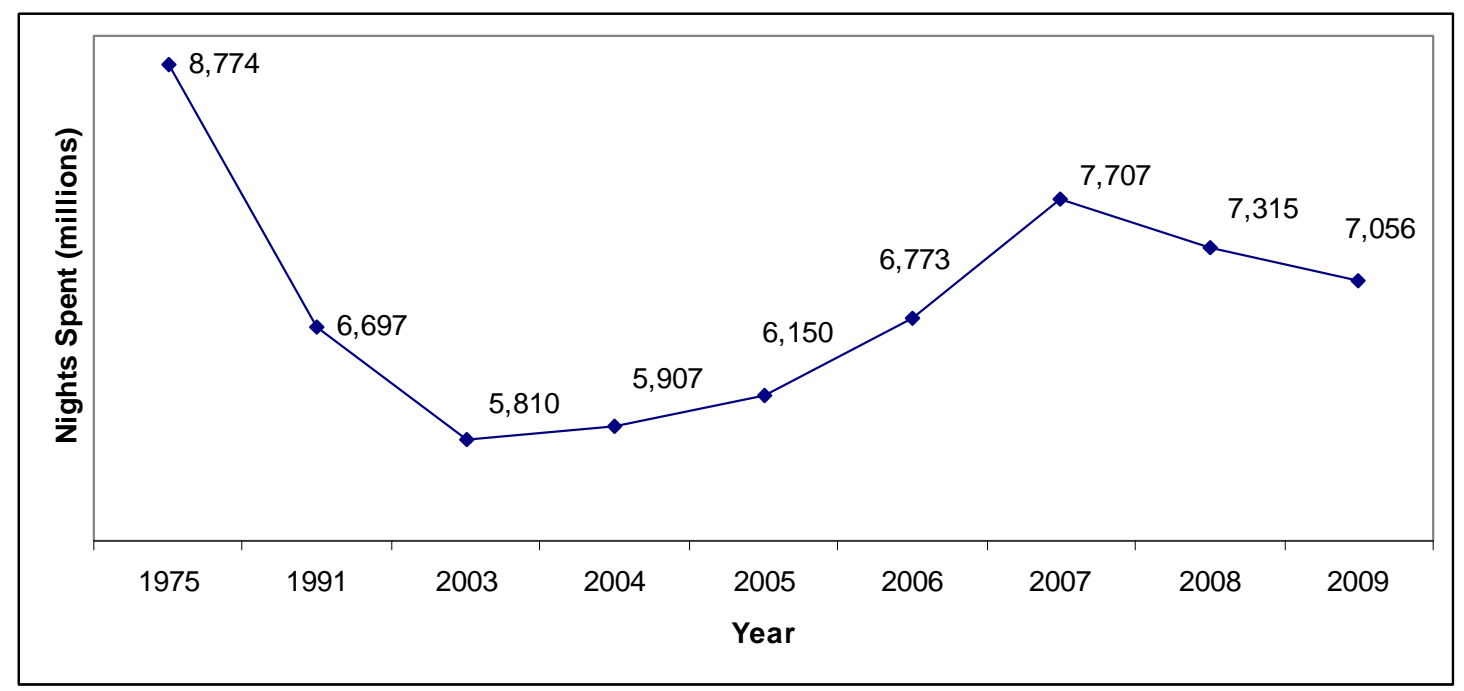

Source: Avgerinou-Kolonia (2002); EL.STAT (2003); EL.STAT (2005); EL.STAT (2007); EL.STAT (2009) 
Figure 2. A Strategic Planning Framework for Leveraging Post-Games Olympic Tourism
LEVERAGEABLE RESOURCES

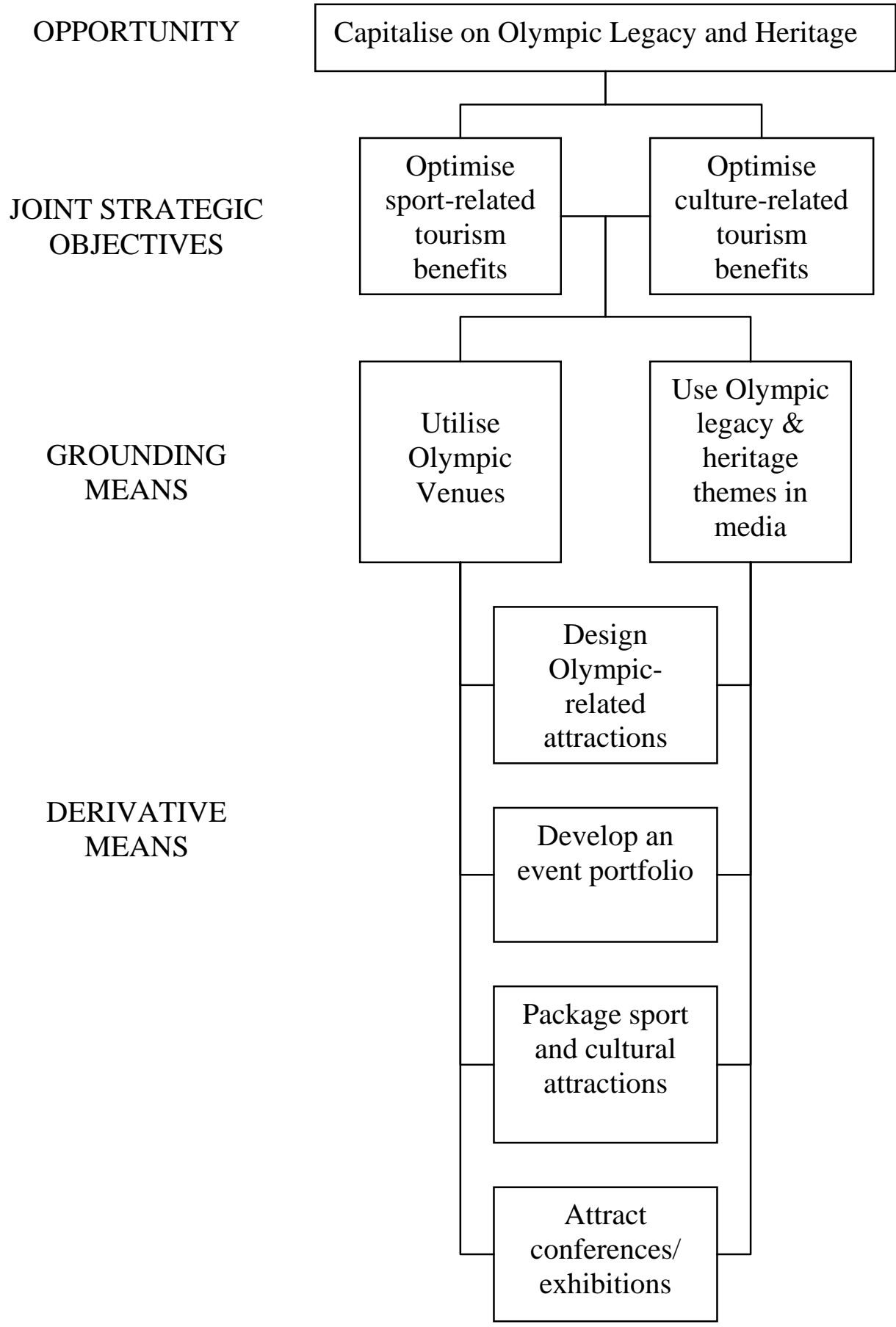

